\title{
Da Seleção à Avaliaçáo: uma análitse dos fatores inibidores da evasão de estudantes nos Mestrados em Educação
}

\author{
CÁSSIO MIRANDA DOS SANTOS \\ Professor de Didática e Filosofia da Educação no UNI-BH \\ Mestre e Doutor em Educação pela UNESP/Marilia - SP \\ cassiom@unibh.br
}

\begin{abstract}
Resumo
O presente artigo trata dos fatores que poderiam conter a evasăo de estudantes nos mestrados em Educaçăo no Brasil. Dada as peculiaridades dos ingressantes nesta modalidade de mestrado tais fatores podem ser levados em consideraçüo na busca pela reduçăo do nível de abandonos e desisténcias. Para uma análise mais precisa fez-se uso dos dados relativos à evasão de estudantes do mestrado em Educação da Unesp/Marilia, das coortes de 1988 a 1995. Foram apontados fatores inibidores da evasalo desde a seleçâo dos candidatos ao mestrado, passando pelo processo de orientaçăo, financiamento, até os critérios de avaliaçăo, com um destaque para a questấo da exigência da dissertaçăo como trabalho final.

Palavras-chave: Mestrado, orientação, seleção, avaliaçăo, dissertaçāo.
\end{abstract}

\section{Resumen}

Este articulo trata de los factores que podrian frenar la evasion de los estudiantes de los cursos del master en Educación en Brasil. Dada las peculiaridades de los que ingresan en esta modalidad del master, tales factores pueden ser llevados en cuenta al estudiar la manera de reducir el nivel de abandonos y evasiones escolares. Para un análisis más exacto fueron utilizados datos relativos a la evasión de estudiantes del master en Educación de la Unesp / Marflia, de los "coortes" (promociones) de 1988 a 1995. Se señalaron factores inhibidores de la evasión desde la selección de los candidatos al master, seguido del proceso de orientación y financiación, hasta los criterios de evaluación especialmente en la cuestion de la exigencia de la disertación como trabajo de conclusión del master.

Palabras-clave: Master, orientación, selección, evaluación, disertación.

\section{Abstract}

This article deals with the factors that could restrain the drop-out rate in Master's Programs in Education in Brazil. For a more precise analysis the data relative to the evasion of Master's students in the Education Program at Unesp/Marilia between 1988 and 1995 were used. Inhibiting factors were pointed out ranging from the selection of candidates for the Master's Program, through the supervising process, financing, to the evaluation criteria, with special emphasis on the requirement of a dissertation as a final product.

Keywords: Master's Program, supervision, selection, evaluation, thesis. 
O jornal O Estado de S. Paulo, em maio de 1995, publicou matéria tratando do Encontro Nacional sobre Pesquisa e Pós-graduação nas universidades brasileiras, na qual revelava que a média nacional de evasão dos alunos de pós-graduação chegava a $50 \%$ (segundo a Capes, o índice geral de evasão nos cursos de pós-graduação stricto sensu no Brasil em 1975 foi de $50 \%$, caindo para $45 \%$ em 1985). A mesma matéria destacava a condição das três universidades estaduais paulistas (USP, Unicamp e Unesp), nas quais a taxa de evasão, $20 \%$, era bem inferior à média nacional (mais recentemente, em agosto de 1998, a Capes informava que a média nacional de evasão era de $25 \%$ ). Muito embora o índice de evasão nas universidades paulistas estivesse, segundo a reportagem, aquém do nível do pais, era possível considerar tal porcentagem ainda elevada.

A formação de mestres é uma questão extremamente importante diante da crescente demanda das instituições de ensino superior por docentes com cursos de pós-graduaçâo stricto sensu. Possivelmente em razäo da curta história da pós-graduação nacional, ocorre considerável defasagem entre o número de instituiçôes de ensino superior e o número de docentes com pós-graduação stricto sensu. Segundo Severino, "o ritmo da formação pós-graduada, lento por sua própria natureza, não podia mesmo acompanhar o ritmo da demanda por professores universitários" (Severino: 190). Tal situação se tornou mais crítica diante do parâmetro estabelecido no segundo item do Artigo 52 da LDB, aprovada em 1996, de que as universidades devem ter um terço do corpo docente, pelo menos, com titulaçāo acadêmica de mestrado e doutorado.

Entre 1996 e 1999, desde o início do processo de avaliação das Instituiçōes de Ensino Superior realizado pelo Ministério da Educação (o "Provão"), houve um aumento de $38 \%$ no número de docentes mestres e doutores nas instituiçôes particulares (Gois: 32). Tal aumento indica que a pressão feita pelo Governo, estabelecendo e exigindo a observancia dos padrōes de qualificação, foi um grande "incentivo" tanto para docentes, que passaram a buscar tal qualificação (traduzida na obtenção do título), quanto para as instituições, que passaram a priorizar a contratação de docentes titulados.

$O$ acesso a um programa de pós-graduação sem a esperada continuidade e conclusão é uma questão que merece ser tratada com atenção, principalmente em razăo daqueles candidatos que não conseguiram vaga, perdendo-a para alguém que não iria usufruir integralmente do curso. Outro fator que agrava o problema refere-se aos altos gastos envolvidos neste processo de admissão-evasão; segundo estimativas de 1995, o prejuizo da Unicamp com as evasões nos cursos de 
mestrado e doutorado chegou a US\$ 1 milhão por ano. (O Estado de S. Paulo 16/5/95: A 16)

O tema evasão tem recebido nos últimos anos um tratamento especial por parte de educadores, principalmente focalizando o ensino fundamental e médio. Termos como abandono, exclusão, fracasso e repetência têm sido empregados com relação aos alunos que não obtêm sucesso na carreira escolar, evadindo-se do sistema em algum momento do curso (Brandão, 1983; Kafuri, 1985; Soares, 1986; Rodrigues, 1987; Prado, 1990; Patto, 1993).

A evasão dos alunos dos cursos de pós-graduação, contudo, é um tema ainda pouco estudado e não são muitas as obras e trabalhos que tratam especificamente do assunto. Analisando a pós-graduação no Brasil entre 1965 e 1978, Jesus Alvarenga observou que havia uma demanda significativa pelos cursos enquanto que o número de alunos titulados apresentava-se baixo. Na sua análise, os percentuais de perdas em alguns casos eram superiores aos de alunos titulados (Alvarenga, 1980). O mesmo autor, em pesquisa abordando a pós-graduação da UFF, afirmou: "duas observações importantes podem ser feitas em relação às matrículas e aos alunos egressos com tese defendida. A primeira é a seleção rigorosa que se mantém de um modo geral na admissão aos cursos e a segunda é a continuidade da seleção durante os cursos" (Alvarenga, 1980: 36,53).

DeLuiz, analisando o mestrado em Educação da UFRJ, entre 1972 e 1977 identificou a realização de 383 matrículas no perfodo estudado, das quais 71 referiam-se a alunos que não concluíram seus cursos, o que indicava um considerável percentual de evadidos (18,5\%) (DeLuiz, 1978: 29). Tamberm Lemos, em 1991, e Sueth, em 1995, produziram trabalhos voltados ao estudo da evasão nos mestrados em Educação de universidades do Rio de Janeiro.

A evasão pode se dar devido a fatores internos ou externos aos cursos. São fatores internos o processo e os critérios de seleção de candidatos, a estrutura do curso, o sistema de orientação, o sistema de avaliação. São fatores externos o contexto familiar do aluno, a conjuntura sócio-econômica nos mais diversos níveis, do local ao internacional, o quadro politico, o contexto cultural. "No Brasil, a evasăo de estudantes parece ser uma característica geral da educação em todos os niveis de ensino, do primeiro grau à pós-graduação, da escolarização regular ao ensino supletivo e não-convencional." (Prado, 1990: 2).

Tratar de evasão em um mestrado implica também definir e classificar o termo mestrado. $\mathrm{O}$ mestrado pode ser visto de várias formas: como um período de alargamento dos conhecimentos obtidos na graduação, sem o necessário caráter pragmático de imediata aplicação 
profissional; como um "degrau acadêmico" inerente àqueles que pretendem dar continuidade aos estudos rumo ao doutorado; como um momento de qualificação docente visando o magistério superior; como uma oportunidade de formação de pesquisadores dentro da universidade ou como um curso de formação de profissionais de alto nível para o mercado de trabalho em empresas públicas ou privadas.

Em síntese, há duas formas básicas de se entender o mestrado: como um dos degraus da carreira acadêmica, ou como um ponto terminal. $\mathrm{Na}$ primeira forma, o mestrado é encarado como um estágio rumo ao doutorado; esse é o caso da universidade francesa, onde o mestrado (a maîtrise) é um pré-requisito àqueles que aspiram o doutorado. Nessa mesma linha está a Universidade de Liverpool onde "um estudante de pósgraduação não pode cursar simultaneamente o mestrado e o doutorado, mas pode obter o grau de master quando fracassa neste ultimo". (Graciarema: 266)

Na segunda forma o mestrado é encarado como um curso completo. Tal curso pode ser, "acadêmico", visando dar um preparo para a docencia de nível superior ou uma oportunidade de pesquisa cientifica, como têm sido a maioria dos mestrados brasileiros desde sua implantação. O mestrado como curso completo pode, também, ser "profissional", dando capacitação e treinamento de alto nfvel voltados para o mercado de trabalho.

O estudo e discussão a pós-graduação está inserido na discussão do papel da universidade contemporanea. Segundo Boaventura Souza Santos, a universidade do final do século $X X$ sofre os efeitos da pós-modernidade $e$ está em crise. A universidade moderna pautou-se pela busca do saber, pela ênfase na pesquisa científica e por uma postura dicotômica diante da relação teoria-prática ou educação-trabalho; a universidade pós-moderna, por seu lado, está se caracterizando pelo pragmatismo, se distanciando da "torre de marfim" onde se localizou por décadas e séculos.

Inserida na universidade a pós-graduação sofre também os efeitos dessa crise e passa por um periodo de redefinição e reafirmação, sobretudo no Brasil. O modelo brasileiro de pós-graduação apresenta uma série de peculiaridades, cujos reflexos são inúmeros e graves, dentre os quais está a evasâo de alunos. Alguns aspectos, no tocante aos mestrados brasileiros, sobretudo na área de Educação, podem e devem ser considerados e estudados para a redução dos indices de evasão de estudantes. 


\section{O Acesso Ao Mestrado: o valor da seleção}

$\mathrm{O}$ acesso aos cursos de pós-graduação facultado a egressos de qualquer graduaçăo (como no caso dos mestrados em Educação) e de qualquer instituição pode tornar-se um fator de risco para o sucesso do curso. Um problema sério dos programas de pós-graduação é o da seleção de candidatos que não trazem uma "bagagem" mínima compativel com o nível acadêmico de um mestrado, sobretudo

"egressos de universidades onde nem sempre o preparo básico é satisfatório. Nesses casos o exame da vida escolar e de outros elementos curriculares poderão servir para verificação de aptidōes, quando complementados com provas de conhecimento e, sobretudo, entrevistas pessoais" (G6es: 229).

Prado, em sua análise da evasão na graduação em Física da USP, chega a uma conclusão semelhante: "Onde o acesso é livre há grande evasão escolar no primeiro ano, chegando a 50\% dos ingressantes, enquanto que nos demais a evasão é menor, mas não desprezivel" (Prado, 1990: 8). A frouxidão na seleçâo é um fator que favorece a evasẫo. Gós entende que a facilidade de acesso é causa do fracasso de muitos alunos.

"Assinale-se que, sem a adoção de um sistema seguro de aferição da capacidade dos candidatos à pós-graduaçäo, se corre o risco de ter uma elevada 'mortalidade acadêmica', o que é grave inconveniente, maximé se são concedidas bolsas de estudo, o que causa perturbaçôes administratioas junto às agências de financiamento" (G6es: 229).

Campos também criticou a facilidade de acesso aos cursos de pósgraduação. "Exemplo é a significativa existência de individuos graduados, formalmente, isto é, considerados habilitados em virtude da posse de um diploma de nfvel superior, que não têm infra-estrutura para acompanhar a pós-graduaçâo respectiva" (Campos 1972: 238). Diante da diversidade de origens dos mestrandos em Educação, muitos acabam utilizando as disciplinas para suprir deficiências da graduação. Segundo Chagas Filho, "os cursos de pós-graduaçăo têm servido precipuamente para remediar falhas dos cursos de graduação. Ora, se a graduação não funciona ela deve ser consertada, o problema não deve ser transferido para a pós-graduação" (Chagas Filho, 1972: 245).

Sarmento identificou, em sua pesquisa junto aos pedagogos e aos egressos de mestrados em Educação, que estes últimos "reproduziam os cursos de Pedagogia, em nfvel mais elevado, já que não foi possfvel identificar diferença significativa de comportamento entre os dois grupos que fizeram parte do estudo" (Sarmento: 111). Segundo a autora, a percepção dos mestres em Educação, acerca dos problemas educacionais 
brasileiros, em pouco ou nada diferia da visão dos egressos dos cursos de Pedagogia.

Considerando a origem acadêmica dos alunos dos cursos de pósgraduação em Educação, surge a suspeita de que assim como há a imagem de que a licenciatura é uma graduação de segunda classe, haveria também a imagem de que o mestrado em Educação seria uma pós-graduação de segunda classe. Há a hipótese, inclusive, de que o fato de grande parte de seus alunos virem de licenciaturas abaixaria o nfvel do curso.

As licenciaturas são, geralmente, os cursos com menores "relaçōes candidatos/vaga" nos vestibulares para universidades públicas. No caso dos cursos noturnos, seus alunos são também trabalhadores, cujo tempo para dedicação aos estudos "extra-classe" é escasso, o que pode ocasionar deficiências na formaçẫo acadêmica. As principais razōes levantadas para a baixa remuneração do trabalho docente estão correlacionadas com o perfil dos alunos das licenciaturas, cuja composição é predominantemente feminina (o que merece uma discussão mais aprofundada para se identificar se a mesma é causa ou consequência da baixa remuneração), de "não aprovados" em vestibulares para outros cursos superiores (tendo, assim, a licenciatura como $2^{\mathrm{a}}$ opção) ou de concludentes de outros cursos superiores que não se encaixam no mercado de trabalho (Santos, 1998).

A área de Educação normalmente gera um sentimento de familiaridade, que leva muitos a julgarem-se aptos a profundas reflexø̃es teóricas e afirmações categóricas sobre assuntos educacionais. Anton Makarenko sintetizou com precisāo essa verdade ao dizer: "É fácil falar de amor, como aliás da pedagogia. São temas conhecidos. Toda gente se diz especialista da matéria" (Makarenko apud Capriles, 1989). Dentre os cursos de pós-graduação stricto sensu, o de Educação é, no senso comum, o menos estrito (diferentemente de outros cursos, sobretudo nas áreas de ciências biológicas e exatas, cuja especificidade é bem clara e definida).

Muitos programas têm procurado apurar seu critério de seleção de alunos. A seleção para ingresso no mestrado em Educação da FaE/UFMG, por exemplo, tem um componente que valoriza a experiência e a história de vida profissional dos alunos. Além das provas e entrevistas os candidatos devem apresentar um memorial sobre sua trajetória na Educação. Segundo Miguel Arroyo, uma das importantes inovações do Programa da $\mathrm{FaE}$ foi a redefiniçäo dos critérios de seleção, ao passarem a dar mais importancia à prática dos candidatos, ao memorial, à sensibilidade com a experiência social e pedagógica (Arroyo in Paiva: 50).

Há aqueles que entendem que um critério que poderia "apurar" um pouco mais a seleçāo seria a exigência de apresentação de um certificado de pós-graduação lato senstu em Educação como pré-requisito 
para o acesso ao mestrado. Carlos Chagas Filho defendia, já no início da década de 70 , a idéia de que o candidato a um mestrado deveria cursar antes uma pós-graduação lato sensu, dentro da área de especialização profissional pretendida (Chagas Filho apud Oliveira, 1995).

Uma seleção mais rigorosa, com a exigência de um memorial que comprovasse o efetivo envolvimento do candidato com questð̃es ligadas à Educação seria de extrema valia, uma vez que muitos acabam ingressando no curso sem o devido "pendor" para a área, s6 descobrindo tal falta de sintonia com o curso já em andamento. A inadaptação pode ser inclusive com a área de concentraçāo do programa. Bernadete Gatti, em 1982, diagnosticou que,

"embora a escolha que faz do programa tenha um componente relativo à área de concentraçäo, näo é esta a motivaçāo mais determinante. O que motioa é, em geral, a facilidade de acesso: ou porque reside na cidade que tal programa é oferecido, ou reside em cidade que lhe facilita o acesso a determinado centro; $e$ assim o candidato à pós-graduação adapta-se à área de concentração oferecida" (Gatti, 1982: 6).

A heterogeneidade de origens acadêmicas propicia, contudo, uma diversidade que pode ser extremamente positiva e rica para o curso, diante das diferentes visões e leituras que podem ser feitas da realidade educacional.

Além disso, consta da Avaliação da Capes do Biênio 96/97 que o corpo discente da área de Educação "melhorou muito, até porque muitos Programas tomaram o cuidado de conter os ingressos em função da redução do corpo docente. Mas o número de titulados em relação aos abandonos e desistências carece de cuidados especiais" (Brasil, Capes, 1998: 41).

\section{A dedicação ao curso: o valor do financiamento}

Os gastos com o curso sem o auxflio de uma bolsa de estudos ou com o auxílio de uma bolsa insuficiente é outra possível explicação para a evasão. A política de concessão de bolsas de estudo para pós-graduação tem sido marcada pela escassez que promove uma "redução quantitativa e qualificativa das pesquisas associadas às atividades de pós-graduação; alto fndice de evasão dos alunos e baixo rendimento global" (Brandão, 1986: 28). Ao analisar a evasão de estudantes no mestrado em Educação da Unesp/Marilia1, constatou-se que somente 9 dos 41 que não conclúram seu

1 Dados constantes da tese "Tradiçōes e contradiçỏes da pós-graduação no Brasil uma análise da evasão de estudantes no mestrado em educaçăo da Unesp/Marilia", Unep/Marillia, outubro de 2000. 
curso receberam uma bolsa de estudo da Capes ou CNPq, o que revela que $78 \%$ dos evadidos não receberam ajuda financeira, por intermédio da Secretaria de Pós-graduação, para a realização do curso (Tabela).

\section{Bolsas - Mestrado em Educação da UNESP/Marilia} Coortes de 1988 a 1995

\begin{tabular}{|l|c|c||c|}
\hline \multicolumn{1}{|c|}{ Condição } & Mestres & Evadidos & Total \\
\hline \hline Bolsista & $69(46,9 \%)$ & $9(22 \%)$ & $78(41,5 \%)$ \\
\hline \hline Não Bolsista & $78(53,1 \%)$ & $32(78 \%)$ & $110(58,5 \%)$ \\
\hline \hline Total & 147 & 41 & 188 \\
\hline
\end{tabular}

Fonte: Secretaria de pós-graduação da Unesp/Marilia

Esses dados nos permitem chegar a algumas conclusôes interessantes: a maioria $(53,1 \%)$ dos alunos que conclufram seu curso o fizeram sem o auxilio de uma bolsa de estudo (Tabela); das 69 bolsas distribuidas 53 vieram do $\mathrm{CNPq}$ e 16 da Capes (11 sob a sigla D.S. Demanda Social). Pode-se afirmar, então, que a bolsa, embora seja um auxflio significativo, não foi condição sine qua non para a conclusẫo. $\mathrm{O}$ fato de receber uma bolsa de estudos foi, contudo, fator significante para o sucesso do aluno no curso, já que dos 78 bolsistas, 69 (88,5\%) o conclufram, enquanto que e a maioria dos alunos evadidos (78\%) não foi beneficiada por uma bolsa. Mesmo havendo bolsistas dentre os evadidos, a porcentagem se mostrou pouco significativa (9, dos 41 evadidos, ou $22 \%$ ), sobretudo levando-se em conta que um desses bolsistas não usufruiu integralmente da bolsa por problemas de saúde (das 9 bolsas, 7 vieram do CNPq e 2 da Capes (D.S.).

As bolsas oferecidas aos alunos de pos-graduação não são garantia de estabilidade para se fazer o curso, por estarem "sujeitas a atrasos e depreciação de valor, além de incapazes de proporcionar aos estudantes condições para dedicação integral". Além disso, "para os estudantes que tenham que se deslocar com suas famillias para estudar em outras regiöes, as bolsas deveriam prever os custos de mudança e instalação" (Schartzman, 1985: 82).

A dedicação integral implica, segundo o $\mathrm{CNPq}$, na comprovação de afastamento do emprego e, segundo a Capes, na mesma comprovação acrescida do registro de que o afastamento se dara "sem rendimentos". Tais exigências promovem, eventualmente, um problema ético; não são raros os 
casos de pós-graduandos que omitem dados relativos ao emprego, a fim de conseguirem o benefício da bolsa. Normalmente, o argumento para tal atitude baseia-se no baixo valor pago pelas agências financiadoras (em 1999 o valor médio da bolsa concedida pela Capes ou CNPq para mestrandos era de $\mathrm{R} \$ 720,00)$. A situação torna-se mais crítica quando se considera o aluno de um mestrado em Educação, cuja faixa etária média e estado civil implicam maiores demandas financeiras (responsabilidade com a alimentação e escola para os filhos, aluguel, impostos, etc.) Segundo Cunha, "a bolsa nem sempre é previsivel quanto à data do pagamento, daf ser indispensável levantar a hipótese de existir uma dose de bom senso na acumulação de trabalho e rendimentos." Dessa forma muitos alunos são levados a desenvolver

"técnicas de sobrevivência na pós-graduação que, infelizmente, não contribuem para elevar o nível. Mesmo quando existem bolsas de estudo em quantidade suficiente, elas näo resultam em diminuição do tempo de execução das dissertaçôes, nem da melhoria de sua qualidade" (Cunha, 1991: 65).

Closs, em 1978, já identificava a predominancia de alunos com experiência profissional dentre os pós-graduandos em Educaçăo (Closs, 1978). Tal experiência é extremamente significativa e muito valorizada em diversos cursos, como no caso da FAE/ UFMG, que inovou,

"remando contra a intposição das agências que só concedem bolsas de estudos exigindo liberação e dedicação exclusiva à pós-graduação, que os pósgraduandos não se afastem da prática. Manter o vinculo profissional ou o contpromisso com o movimento social é importante porque se pretende refletir teoricamente sobre a prática; é produzir a partir dessa reflexäo" (Paiva: 27).

A bolsa confere ao aluno de pós-graduação a possibilidade de se dedicar ao trabalho de pesquisa. Conjugar a pesquisa, visando a elaboração da dissertação com a docência, em áreas que, na maioria das vezes, não estão em sintonia com o tema pesquisado, é uma tarefa diff́cil e por vezes desestimulante. $\mathrm{Na}$ fase de confecção da dissertação, näo raras vezes, o pesquisador está sentado à frente de seu computador digitando um texto, ou na biblioteca absorto na leitura de um livro e tem que interromper o trabalho para se dirigir à sala de aula para cumprir suas funçöes como docente. Essa quebra no processo de pesquisa é muito problemática. Com a bolsa o mestrando pode se dedicar ao projeto e as interrupçöes tornam-se menos frequentes. A interação ensino-pesquisa é de suma importância para a vida acadêmica, contudo, há períodos em que há a necessidade de uma dedicação integral para a obtenção de qualidade no trabalho de pesquisa. Seguindo essa linha de raciocínio, diversas instituições de ensino superior, sobretudo públicas, concedem aos seus docentes-pesquisadores anos ou 
semestres sabáticos. Paradoxalmente, nesses períodos sabáticos a produtividade de muitos aumenta sobremaneira, possivelmente porque o "descanso" (sabá na língua hebraica) em questão refere-se somente à docência, não à pesquisa.

De acordo com o Relatório da Comissão Nacional para Reformulação do Ensino Superior, de 1985, a falta de recursos gera grandes instabilidades nos programas de pós-graduação. "A instabilidade se reflete ainda nas bolsas de estudos oferecidas aos alunos de pós-graduação, sujeitas a atrasos, depreciação de valor, e incapazes, na realidade, de proporcionar aos estudantes condiçōes para dedicação integral de seus estudos" (Brasil, Ministério da Educação, 1985: 79). Diante dessa constatação a comissão propôs uma revisão do sistema de bolsas de estudos de pós-graduação,

"tratando de dar aos estudantes remuneraçẫo adequada para a dedicação efetiva ao temrpo integral, apoio no periodo de realização de trabailhos de teses e cobertura social correspondente à dedicação profissional aos estudos, incluindo pelo menos os beneficios da previdência social" (Brasil, 1985: 80).

A revisão compreenderia também os problemas dos custos de viagens, mudanças e instalação de alunos arrimos de família, que tivessem que se deslocar de suas regiōes para realizarem seus cursos.

A questâo financeira pesa na decisão de abandonar o curso não só entre os alunos de Educação. No mestrado em Engenharia da UFRJ a evasāo já chegou a $50 \%$. Uma das hipoteses mais aceitas é de que

"uma das causas da eoasão neste setor seja a grande procura de profissionais pela indústria. $O$ aluno que está frequlentando o curso em tempo integral, com um grande desgaste intelectual, desde que não tenha muita motivaçäo, responderá ao primeiro bom convite para trabalhar numa empresa" (Bravo, 1972: 390).

O aluno de pós-graduaçāo em Educaçāo, por sua vez, pertence normalmente a uma faixa etária mais avançada que em outras áreas. A maioria dos ingressantes nos mestrados em Educação não iniciam sua pósgraduação logo em seguida ao curso de graduação devido a diversos fatores como compromissos profissionais ou familiares. A idade implica, via de regra, tais compromissos que dificultam a sua conciliação com o estudo e a pesquisa (Beiguelman, 1990: 19; Rodrigues, 1987).

Falar de faixa etária média dos alunos dos mestrados em Educação implica tocar no problema da idade "ideal" para se realizar uma pesquisa. Foi grande a polêmica levantada em 1996, em torno das afirmaçōes feitas pelo então diretor científico da Fapesp, José Fernando Perez. Segundo ele, o país estava formando pesquisadores velhos, que passariam grande parte de 
suas carreiras acadêmicas em processo de formação, o que se tornava mais grave quando se tratava da área de Educação, visto que, segundo Perez, havia "um certo retardo na pós-graduação nas áreas das ciências humanas e sociais em comparação com a das ciências da natureza" (Brasil, SBPC, 1996: 4). A "gota d'água" se deu quando Perez, durante um debate no $20^{\circ}$ Encontro Nacional de Pesquisa e Pós-graduaçāo em Ciências Sociais, afirmou que "pesquisador velho é pesquisador morto" (Brasil , SBPC, 1996: 10).

É passfivel de discussão a avaliação da viabilidade da pesquisa tendo como um dos critérios a faixa etária do pesquisador. Segundo Faria, não há como

\begin{abstract}
"estabelecer um limite de idade para que uma pessoa continue a se aperfeiçoar, progredir e aumentar o nível científico e tecnológico de nosso paris. A avaliaçẩo que se espera do $\mathrm{CNPq}$ dos pedidos de bolsas de qualquer natureza devem se ater, exclusivamente, à análise técnica do pedido" (Faria, 1996: 10).
\end{abstract}

Na Alemanha, em 1988, a idade média do aluno da pós-graduação estava entre 28 e 29 anos, se considerarmos somente o nível análogo ao nosso mestrado; se fossem inclufdos os alunos do doutorado a idade média se elevaria para 32 anos (Goldschmidt: 4, 7).

Considerando a faixa etária dos alunos, o índice de evasâo no mestrado deveria ser menor que o índice na graduaçāo. Tal diferença se justificaria em razão da provável maior imaturidade deste aluno em relação àquele. O ingressante na universidade é, normalmente, levado a tomar uma decisäo precocemente, que poderá influenciar todo seu futuro acadêmico e profissional. Aos 16, 17 ou 18 anos tem que decidir, no momento do vestibular, o curso e, por conseguinte, a profissão que abraçará (tal análise se refere, basicamente, aos ingressantes em cursos diurnos de universidades, uma vez que os ingressantes em cursos noturnos têm um perfil diferenciado). O ingressante em pos-graduação já apresenta, principalmente se considerarmos os ahunos dos mestrados em Educação, uma maturidade (em consequência da idade mais avançada) suficiente para optar pelo curso que mais lhe convém. Essa pretensa maturidade, contudo, não garante a permanência do aluno, uma vez que mesmo pessoas maduras podem fazer opçōes inadequadas.

O perfil do aluno da pós-graduação em Educação, contudo, tem provocado reações positivas inclusive dentre os docentes dos programas. Jamil Cury, referindo-se aos alunos do mestrado em Educação da FaE/UFMG, afirmou que em toda sua trajetória naquele programa, a marca mais profunda que teve foi a de ter sido reeducado pelo perfil dos mestrandos. "Estudantes que, ao invés dos alunos 'certinhos' que vi na 
França, eram alunos extremamente ciosos, ambiciosos, questionadores de algumas verdades que eu tinha" (Cury apud Paiva: 53). Tal senso crítico foi observado também dentre os evadidos do mestrado em Educação da Unesp/Marilia, cujas análises das razões de sua safda foram pontuadas de importantes questionamentos e reflexôes (Santos, 2000).

Nos mestrados em Educação, pois, o perfil do aluno é diferenciado, - que implica uma necessária conjugação de estudo e trabalho para a manutenção pessoal e familiar. $O$ baixo valor das bolsas de estudo, em se tratando do sustento de uma familia, não somente de um indivíduo, acaba inviabilizando ou dificultando o curso. A exigencia de exclusividade ao estudo/pesquisa faz com que muitos desistam da bolsa e outros tomem a decisäo (eticamente senão reprovável, pelo menos discutível) de optar por omitir a informação de que estão trabalhando para poder recebe-la. Segundo Eco, a própria confecção do trabalho final de curso "está ligada também a fatores econômicos, pois sem dúvida um estudante que trabalha dispōe de menos tempo, energia e até dinheiro para se dedicar a longas pesquisas" (Eco: 3).

Há, por outro lado, muitos alunos que deixam seus cursos inconclusos por encarar a pós-graduação como uma mera fonte de renda por meio exatamente da bolsa de estudos. Segundo o ex-reitor da Unicamp, José Martins Filho, vários alunos fazem da pós-graduação o seu primeiro emprego e "quando surge uma oportunidade melhor no mercado profissional, eles abandonam a universidade" (O Estado de S. Paulo, 16/5/95: A16). Na França, de forma análoga ao que acontece no Brasil, "encaminham-se também para a pos-graduação aqueles que simplesmente não conseguiram emprego logo após o término da graduaçăo" (Cunha, 1972: 342).

Segundo Alvarenga, a já citada falta de envolvimento ou dedicaçăo à pesquisa poderia ser uma das principais causas da evasão de alunos da pós-graduação. "Criou-se então uma demanda artificial pelos cursos de pós-graduação. Uma parcela significativa dos que a demandam não o fazem com o objetivo de melhor aprenderem a trabalhar" (Alvarenga, 1980: 36).

$\mathrm{Na}$ avaliação da Capes (96/97), no tocante aos programas de pósgraduação na área de Educação, o número de titulados é satisfatório. Segundo a avaliação, o resultado foi bom, não obstante o número elevado de abandonos ou desistências, "fenomeno que tende a ser relacionado diretamente a dois fatores: redução considerável do número de bolsas; valores muito baixos das bolsas de mestrado e doutorado e a consequente necessidade de parte do corpo discente de manter seus vínculos empregatícios" (Capes, 1998: 33). 
A questāo das bolsas para pós-građuandos criou um impasse entre Capes e CNPq. Em 1997, o CNPq questionava o financiamento que estava promovendo, por meio de bolsas, a pós-graduandos (cuja responsabilidade seria a priori da Capes) em detrimento de outros setores de pesquisa. A Capes, por sua vez, reconhecia sua incapacidade de suprir devidamente as necessidades de bolsas na pós-graduação, principalmente com a anunciada retração do $\mathrm{CNPq}$, até então responsável por $50 \%$ das bolsas de pósgraduaçâo no pafs (SBPC, Jormal da Ciência, 1997: 1).

A própria avaliação da Capes identificou o problema relativo ao financiamento das pesquisas em Educação ao reconhecer que "näo se pode ignorar que a piora significativa das polfticas de apoio e fomento nos últimos anos prejudicou muito a área que não é, como nunca foi, objeto de zelo das agências" (Capes, 1998: 41).

\section{O cumprimento dos requisitos (I): o valor da orientação}

Segundo os dados obtidos na secretaria da pós-graduação da Unesp/Marilia, trabalharam no programa na área de Educação, entre 1988 e 1995, 65 orientadores, dos quais, 26 (40\%) viram pelo menos um de seus orientandos evadir (Santos, 2000). Dos 41 alunos evadidos, 5 trocaram de orientador durante seu curso. Com relação a orientação, alguns outros dados são igualmente importantes: 6 orientadores (isto é, 23\% dos orientadores de alunos evadidos ou $9,2 \%$ do total de orientadores do programa) viram 3 de seus orientandos evadirem, o mesmo ocorrendo com 5 outros orientadores $(19,2 \%)$, que viram 2 de seus orientandos evadirem. No geral, percebemos que 23 dos 41 evadidos (56\%) foram orientados pelos mesmos 11 orientadores, o que reforça a análise feita por alguns dos alunos evadidos da existencia de orientadores mais "desmotivadores" que outros (na Unesp/Marilia, no perfodo de curso das disciplinas, o contato com o orientador é bem esporádico, sobretudo nos casos dos orientandos ou orientadores que residem fora da cidade, o que torna lento o avanço da pesquisa).

A questão da orientação é um item de muito valor na avaliaçăo feita pela Capes. O número de orientadores NRD6 em relação a dimensão do corpo docente tem peso 25 na avaliação do item "Atividades de Formaçăo"; a dimensão do corpo discente em relação à dimensão do NRD6 tem peso 30 no item "Corpo Discente"; e o número de orientadores em relaçăo à dimensão do NRD6 tem peso 10 na avaliação do item "Teses e Dissertaçōes" (NRD6 é o "docente SP/CLT com periodo mínimo de 9 meses de atividade no Programa, com regime de trabalho minimo de 30 horas semanais e dedicação ao Programa superior a 30\% da carga horária 
contratada, todos no Ano-Base" Capes, 1998: 6). A Capes, em sua avaliação divulgada em 1998, identificou certa falta de equilibrio nas atividades de orientação naquele programa. Segundo a avaliação alguns orientadores do programa de Marilia tinham uma sobrecarga de orientandos, de 7 a 9, enquanto outros orientavam somente um ou dois alunos (Capes, $1998: 4$ ).

A avaliação da Capes $(96 / 97)$ revelou o baixo indice de dissertações orientadas por orientador, "vários comitês destacaram o fato de que há muitos docentes produtivos sem orientandos e o de que a orientação e a produção não serem uniformemente distribuidas entre os docentes de um mesmo curso" (Zancan, 1997).

São muitos os problemas que podem surgir em decorrência do sistema de orientação: incompatibilidades entre orientador e orientando, dificuldades de relacionamento, divergencias pessoais ou metodologicas. Tais fatores podem proporcionar um ambiente pouco estimulador e propício à pesquisa.

Dentre os problemas que podem surgir na orientação, está o caso dos orientadores de pesquisa que se valem de seus orientandos para a execução de projetos pessoais. Muitos vêem "no seu aluno, não um futuro colega, mas um auxiliar precioso que poderá ajudá-lo na execução de seus projetos de pesquisas" (Chagas Filho, 1972: 244). Não são raros os casos de mestrandos que não passam de meros "tarefeiros", cujas pesquisas limitam-se à coleta de dados visando o suprimento da pesquisa maior de seu orientador.

Muitas vezes a escolha do tema da dissertação é do próprio orientador, não do orientando, o verdadeiro responsável pelo trabalho de pesquisa. Segundo Eco, muitas vezes, "o professor está entusiasmado com seu próprio tema e violenta o candidato que, por seu lado, não tem o mínimo interesse naquela direçấo" (Eco: 33 ).

Em pesquisa realizada junto a orientadores e alunos de pósgraduação (doutorandos) de universidades dos Estados Unidos, Paul Issac identificou que "os fatores que afetam a escolha dos temas incluem a preferencia do orientador, tendências do campo, a probabilidade de a pesquisa ser publicada, e o ganho projetado da pesquisa sobre a expectativa de emprego do estudante". A pesquisa revelou também que " $31 \%$ dos estudantes indicaram que fizeram a seleção (do tema) com 'input' do orientador ou do conselho de curso" (Issac: 368).

Nessa pesquisa, o grupo do Prof. Issac identificou diferenças na avaliação do trabalho do adviser (orientador) dependendo de sua área de atuação. Em termos comparativos, os orientadores de ciencias humanas foram considerados piores em acompanhamento e assistencia que os de outras áreas: 
"...as áreas variam no que se refere à adequabilidade de acompanhamento do orientador $e$ do conselho. Por exemplo, nas Ciências Administrativas, Educaçäo e Humanidades, o orientador e o conselho variam de 0,2 a 0,3 unidades na escala de avaliaçẫo. Em contraste, nas Ciências Biologicas o orientador tem um nível favorável $(4,0)$ enquanto que o conselho de curso tem um nível neutro ou desfavorável (2,8), uma diferença de 1,2 unidades. Similarmente na Engenharia (diferença de 0,9), Matemática e Ciências Físicas (diferença de 1,3), e Ciências Biológicas Profissionais (diferença de $0,7)$, os orientadores são substancialmente melhor considerados pelos estudantes" (Issac: 370).

O que se depreende da análise acima é que a natureza da pesquisa determina o grau de influência e de valorização do acompanhamento pelo orientador. De fato, as pesquisas que demandam o uso de laboratório e a supervisão constante, por exemplo, em Química e Biologia, sâo as que mais exigem e, por conseguinte, valorizaram o trabalho do orientador. Muitos alunos encontram, por outro lado, sérias dificuldades em serem orientados, por efetiva falta de experiencia dos orientadores. Segundo Cunha,

"se formos procurar as pesquisas que os orientadores fizeram sobre os temas dos trabalhos que orientaram, encontraremos pouquíssima coisa. Ora, como é possivel orientar bem um trabalho sobre um tema que não se pesquisa? Será que a formaçāo de nossos orientadores é assim tão transferíoel?" (Cunha, 1991: 66).

Eco, por outro lado, entende que além da tradicional orientação de pesquisa sobre um assunto que domine, é até interessante que um professor se prontifique a orientar um trabalho de pesquisa cuja temática seja para ele desconhecida ou pouco conhecida.

"Fique claro que, contrariamente à primeira impressão, esse segundo critério é mais honesto e generoso. O professor raciocina que, acompanhando uma tese dessas, terá seus próprios horizontes alargados, pois se quiser avaliar bent o candidato e ajudí-lo em seu trabalho terá de debrucar-se sobre algo nowo. Em geral, quando o professor opta por essa segunda via, é porque confia no candidato. E normalmente the diz explicitamente que o tema é novo para ele também e que está interessado em conhtecê-lo melhor" (Eco: 33).

A produção de uma dissertação exige um interlocutor, a redação de um texto "é um exercício de comunicação que presume a existência de um público: e o orientador é a única amostra de público competente à disposição do aluno no curso de seu trabalho" (Eco: 15). Nos Estados Unidos, como citado anteriormente, há a figura do adviser, que atua como um tutor dos alunos, "que aconselha e fiscaliza cada estudante sob o aspecto de que este mantenha seu currículo dentro de um nfvel compativel 
com o grau que pretende obter e impede que ele se submeta a uma carga horária excessiva" (Kamergorodski, 1972: 348).

O trabalho de acompanhamento do orientador é de grande importância para o sucesso do trabalho do aluno. Um acompanhamento constante é extremamente valioso, apesar do risco da manutenção de uma relação marcada pela heteronomia, uma vez que o contato do orientador com os resultados da pesquisa vai se dando gradual e crescentemente. "Uma tese de última hora obriga o orientador a devorar rapidamente os capítulos ou a obra já pronta. Caso a veja no último momento e não goste, poderá criar dificuldades ao candidato na banca examinadora, com resultados bem desagradáveis" (Eco: 15).

A estrutura e propósitos dos mestrados acadêmicos, que transcendem as relaçōes e produçōes intra-sala de aula, exigem a presença constante de um orientador

"com maior tempo de contato entre este e o aluno, seja no laboratório, seja em sua biblioteca, do que aquele utilizado em seminários e aulas de qualquer tipo. Uma das consequências desse fato é a de que a relaçäo docente/aluno num curso de pós-graduação deve ser muito limitada, e o papel do orientador assume assim muito mais alto significado" (Chagas Filho, 1972: 243).

A atuação do orientador é significativa também para se evitar fraudes na elaboraçāo das dissertações. A estratégia utilizada por alguns alunos de contratarem ghost-writers para elaborarem seus trabalhos fica praticamente inviabilizada se tal aluno recebe um acompanhamento atento e constante de seu orientador.

Ivani Fazenda consegue demonstrar o valor do trabalho de orientação, ao relatar que durante esse processo passa

"todo o tempo como obseroador de fora, que ajuda o outro a olhar, a enxergar além do visivel - como é incrivel poder contemplar o belo pelos olhos de outrem. Acompanho todo o processo de gestação e criação do ato de conhecer que perpassa os vários momentos da pesquisa - a cada dificuldade superada vejo educadores crescerem, tornando-se identidades -, da descrença à crença, da impossibilidade ao posstoel, do virtual ao real, do sonhado ao construido..." (Fazenda, 1997: 13).

\section{O cumprimento dos requisitos (II): a questão da avaliação}

\section{O problema da exigência da dissertação}

O "trauma" do desenvolvimento da pesquisa e conseqüente confecção da dissertação é uma das mais importantes causas da evasão de alunos da pós-graduaçāo em Educação, o que pode ser indicado na constataçāo dos altos percentuais de abandono entre a conclusão das 
disciplinas e a defesa da dissertação. Sueth, analisando a evasão nos mestrados em Educação do Rio de Janeiro, identificou a dificuldade de elaboração da dissertação como a principal causa de abandono (Sueth, 1995). Pode-se afirmar que o momento de elaboração da dissertação é um dos ou o principal "gargalo" dos mestrados em Educaçâo (Prado, 1990: 119).

Isso ocorreu na pós-graduação da UNESP/Marilia, onde uma significativa parcela dos alunos evadidos $(48,8 \%)$ concluiu os créditos relativos às disciplinas, tendo deixado o curso exatamente no perfodo da orientação da dissertação (muito embora somente $15 \%$ dos entrevistados tenham indicado a dissertação como o motivo principal de sua saída). A identificação do momento em que ocorre o abandono dos alunos da pósgraduação é de extrema importåncia para se avaliar o grau de dificuldade dos diferentes estágios do curso: as disciplinas, a elaboração do projeto, o desenvolvimento da pesquisa, o exame geral de qualificação e a confecção da dissertação. No caso da Unesp/Marilia, nenhum dos evadidos se submeteu ao exame geral de qualificação (exame que acontece antes da defesa da dissertação). Os dados confirmam o diagnóstico feito pelo professor Hamburger, na década de 70 , de que no "sistema de pósgraduação, o estudante dedica frequientemente mais esforço e tempo aos cursos que à pesquisa" (Hamburger: 80).

Na avaliação da Capes do biênio $96 / 97$, contudo, a conclusão com relação às dissertaçōes dos mestrados em Educação era a de que demonstravam uma tendencia a serem

"cada vez mais indefinidas como trabalhos acadêmicos; seus titulos e resumos sugerem a presença intensa de relatos de experiências pessoais e equivalentes. Assim, muitos trabalhos de doutorado sugerem mais precisäo cientifica $e$ especificidade cognitioa, enquanto as dissertaçöes parecem estar sendo menos cuidadas" (Capes, 1998: 35).

Há, basicamente, três tipos de dissertação. O primeiro é o tipo descritivo, quando se faz uma compilaçāo de outros estudos sobre o tema proposto, com uma finalidade analítica. O segundo é o interpretativo, quando se faz uma leitura original interpretativa do pensamento de um autor, de uma obra ou de uma arte. O terceiro tipo é conhecido como levantamento ou "suroey", quando se procura levantar dados quantitativos acerca de um determinado tema, passando em seguida à sua análise, classificaçâo e descrição dos resultados (Oliveira, 1997:1).

Desde o inf́cio dos cursos de mestrado no país é patente o problema passado pelos pós-graduandos quando se deparam com a necessidade de elaborar a dissertação. No início da década de 70 , a confecção da tese (o trabalho final de mestrado na época) era o ponto crucial do curso "quando 
os candidatos ao tftulo podiam evidenciar ou não o domínio dos conceitos e da metodologia científica, bem como sua capacidade criadora, a modéstia da tentativa de acerto e do erro, além da paciencia para um trabalho de repetiçäo ou rotina" (Revista Brasileira de Estudos Pedagógicos, Editorial, 1972: 212). Nessa década, a oferta de cursos de pós-graduação lato sensu não era täo abundante quanto no final da década de 90, o que acabou por levar muitos dos potenciais candidatos a um curso de lato sensu a se inscreverem em um curso de stricto sensu. Esse perfil do aluno dos mestrados, proporcionou um certo desvirtuamento da pos-graduação stricto sensu acarretando, inclusive, um baixo índice de entregas e defesas de dissertação.

As dificuldades na elaboraçäo e, sobretudo, na confecção da dissertação eram muito maiores nas décadas de 60,70 e início de 80 . Nesta época eram raros os computadores, sobretudo os micro computadores pessoais (PCs), tão comuns no final da década de 90. As teses (dissertaçōes) eram, via de regra, manuscritas e posteriormente encaminhadas para um datilografo. Pequenos erros ou mudanças na paginação, que a partir da década de 90 podem ser solucionados com um simples movimento do "mouse", implicavam muitas vezes perda de dias de trabalho.

Zaia Brandão, ao pesquisar os mestrados em Educação no Brasil entre 1976 e 1984, destacou a pequena porcentagem de conclusões de curso que podia ser entendida como um indicador de que, mesmo atraidos pela titulação, somente a minoria da clientela dos mestrados se mostrava capaz para elaborar o trabalho de final de curso (Brandão, 1986: 28). Gatti tambem apontou como fatores desmotivadores a indefinição quanto ao trabalho final de curso (dissertação) e as dificuldades financeiras para locomoção, moradia, confecção e reproduçāo dos trabalhos. Segundo esta autora, "há cursos que exigem dissertaçōes volumosas e outros que se satisfazem com textos curtos de cinquienta páginas; tal discrepância acaba por deixar os alunos inseguros e intranqütilos com relaçāo à confecção da dissertação" (Gatti: 10). Nas palavras de Coelho "a insistencia indiscriminada e formal na necessidade de pesquisa engendra, em muitos casos, uma pesquisa de qualidade duvidosa e destinada unicamente ao preenchimento de preceitos burocráticos" (Coelho: 89 ).

O momento da elaboração da dissertação é o da transição de uma relação semi-heterônoma do curso das disciplinas (quando o professor determina os textos a serem lidos, as metodologias a serem desenvolvidas e a forma de avaliação), para uma fase em que predomina a autonomia, quando o aluno tem liberdade para escolher o tema de sua pesquisa, a forma de coletar os dados, assim como a metodologia de análise e interpretação. $O$ contraste entre esses dois momentos gera muita ansiedade, 
expectativa e, em alguns casos, frustraçâo, normalmente por ser a primeira experiência efetiva de pesquisa. Segundo Lüidke,

"como se trata de uma experiência vital para o estudante, pois apesar de primeira ela já é 'para valer', valendo mesmo um título importante, o de mesire, essa situação provoca em geral grande tensão entre os mestrandos, chegando mesmo a impedir alguns deles de chegar a bom termo" (Ludke: 113).

O trabalho de pesquisa requer, sem dúvida, envolvimento pleno do pesquisador. Há necessidade de empenho e dedicação muito bem traduzidos por Ivani Fazenda ao afirmar: "subjugamo-nos ao que a pesquisa nos revela de corpo inteiro e, nesse ato de entrega, anulamo-nos para nos tornarmos inteiros, parceiros do conhecimento" (Fazenda, 1997: 13).

É interessante mencionar, também, a indústria de teses e dissertações que existe à margem dos cursos de pós-graduação. Em anúncios classificados de jornais das grandes cidades não é raro se encontrarem ghost-writers oferecendo seus trabalhos ("Faço Monografia. Trabalhos em Economia, História, Psicologia, Educação, Comunicaçāo, etc. Qualidade total. 553-2570. Prof" Fernanda". "Faço trabalhos Faculdade Monografias, teses e outros sem cálculos. Tratar Prof" Cândida 226-9613."). Em 1995, Fábio Altman, em artigo publicado na revista Veja, mencionou o anúncio acima e revelou as estratégias utilizadas para se falsificarem dissertaçöes e teses. No artigo são citados nomes e trabalhos de vários ghost-writers, cujas dissertaçōes e teses foram aprovadas por bancas de conceituadas universidades do pais. Segundo Altman, um desses ghostwriters, identificado como Vianna, atuava num alto padrão: "Ele gosta de teses de mestrado (1 500 reais) e de doutorado ( 3000 ). No texto de seus anúncios, Vianna apela: 'Faça como o presidente Fernando Henrique: tenha seu proprio ghost-writer'", numa menção ao trabalho de Eduardo Graeff, que na época elaborava os discursos do presidente da república (Altman: 62). Em razão de casos como os acima citados, a "desconfiança recai também, e aliás em primeiro lugar, sobre o estudante, que deve estar tentando obter indevidamente os privilégios do título. Transfere-se assim para o nivel pós-graduado o problema da 'cola' e semelhantes" (Hamburger, 1980: 89).

O problema da dissertação se agrava quando se considera que os egressos de licenciaturas não tiveram, necessariamente, experiencia com pesquisa durante a graduação. Tal situação pode implicar dificuldades com a primeira experiência efetiva de pesquisa que se dá na pós-graduaçäo. Ocorre no Brasil um fenômeno similar ao ocorrido na graduação italiana, onde 
"existem inúmeros estudantes obrigados a preparar uma tese, para formar-se logo e obter o scatto di grado que os levou a se matricular na universidade. Alguns destes estudantes têm quarenta anos. Eles pedem instruçōes sobre como preparar uma tese emt umt mês, para tirarem uma nota qualquer e sair da universidade" (Eco: 4).

Segundo Eco, o prazo mínimo para se realizar um bom trabalho científico de final de curso (graduação) é de 6 meses, não sendo aconselhável um prazo superior a 3 anos para se concluir a tarefa de delimitar o tema e coletar os dados. Quando esse período não foi suficiente para o cumprimento destas tarefas o aluno possivelmente chegará a uma de três conclusões: escolheu um tema inadequado; provavelmente tentou dar "um passo maior que as próprias pernas"; não conseguiu ter a objetividade, a precisão e a disciplina necessárias para um trabalho de pesquisa cientifica; foi acometido pela "neurose da tese" (começa a faze-la, pára por um tempo, retoma o trabalho, sente-se desmotivado, entra em depressão). "Valemo-nos da tese como álibi para muitas covardias, não nos formamos nunca" (Eco: 14).

Uma alternativa para a solução desse problema seria a criação de programas de iniciação cientffica no decorrer do curso de pós-graduação, como o ocorrido na PUC/RJ em meados da década de 70 . Segundo a coordenadora deste programa, alguns dos projetos de iniciação cientifica pós-graduada serviram como

"fontes de inspiração para os próprios projetos de dissertação dos mestrandos participantes, que sem exceçäo deram testemunho do beneficio que receberam ao tomar parte no programa. Todos declararam-se mais seguros $e$ desembaraçados no trato com as questōes práticas $e$ teóricas da pesquisa $e$ sempre recomendaram o programa aos colegas que os sucederam" (Ludke: 115).

Segundo a Resolução $\mathrm{n}^{\circ} 5$, de 31 de outubro de 1983, em consonância com o Parecer $977 / 65$, a dissertação não deveria ser a única alternativa para avaliação final do mestrado. O Artigo $2^{\circ}$ da Resolução, em seu item IV estabelecia que:- "Além das atividades didáticas e acadêmicas exigir-se-á do candidato ao grau de mestre a apresentação de dissertação ou outro tipo de trabalho compatível com as características da área de conhecimento" (Brasil, 1983).

A Resolução 12/83 do Conselho Federal de Educação permitiu a concessão de certificado de pós-graduação lato sensu (especialização) àqueles que cursaram uma pós-graduação stricto sensu (mestrado) sem, contudo, elaborarem a dissertação. Há muita controvérsia sobre esse tema. Muitos são favoráveis à idéia, outros consideram-na um demérito, um "prêmio de consolação"; há aqueles que entendem que tal medida 
desvalorizou e desacreditou os cursos normais de pós-graduação lato sensu. Na prática, embora haja a possibilidade legal, diversas instituiçōes, como a PUC-RJ, a UFRJ e a Unesp, não concedem o certificado de especialização àqueles que conclúram os créditos relativos às disciplinas dos mestrados, sem, contudo, defenderem sua dissertação (Oliveira, 1995 : 144).

\section{A alternativa do mestrado sem dissertação}

Para Luís Loureiro, diretor interino da Capes em 1998, a exigencia da confecção da dissertação era um dos maiores problemas dos mestrados tradicionais, daí seu apoio à regulamentação dos mestrados profissionais, que dispensavam a sua apresentação (Jornal Folha de S. Paulo, 19 de julho de 1998). Newton Sucupira, no Parecer 977/65, já admitia uma categoria de mestrado alternativa ao tradicional "mestrado acadêmico". Nas suas palavras, "o Mestrado tanto pode ser de pesquisa como profissional" (Sucupira, 1965: 156). A tentativa de se implantarem mestrados profissionais baseia-se, em certo sentido, na

"idéia de se fazer algo semellhante ao que ocorre nos Estados Unidos e em alguns paises europeus, ou seja, eliminar as dissertaçöes dos cursos de mestrado. Em verdade, em várias universidades desses países já não existe 0 mestrado e esse título não é mais valorizado, salvo em algumas áreas profissionais" (Oliveira, 1995: 161).

Em 1958 foi iniciado o CPG, Curso Pós-Graduado, em Administração na Escola de Administração de Empresas de São Paulo (EAESP) com inúmeras semelhanças ao MBA (Master in Business Administration) norte-americano. As principais semelhanças referiam-se à duração do curso ( 2 anos em regime de tempo parcial ou 1 ano, em regime de tempo integral) e à não exigência de uma dissertação para a conclusão do curso (Oliveira, 1995: 113). A experiência da EAESP é muito interessante uma vez que posteriormente, em 1965, decidiu-se transformar o Curso Pós-Graduado em mestrado. O regulamento do curso definia, em seu artigo 19, que receberia o título de mestre em Administração de Empresas o egresso do antigo CPG que também apresentasse um trabalho monográfico (sob orientaçāo e aprovado por uma banca examinadora), e fosse aprovado em um exame suplementar sobre conteudos do referido curso. O paradoxo de tal situação reside no fato de que um egresso de um MBA receberia imediatamente o título de mestre, enquanto um egresso do CPG (a copia fiel do modelo norte-americano) teria ainda que se submeter a uma série de novas avaliações. Somente em 1993 foi criado na EAESP um mestrado em Administração que não exigia a dissertaçäo no final do curso, à semelhança do MBA norte-americano. 
Ao longo da década de 1990 surgiram diversos cursos de questionável qualidade, sobretudo na área de Administração, valendo-se da fama dos MBA norte-americanos. A questão financeira acaba sendo determinante na opção de muitos por estes cursos:

"Consultores e empresas estimam que, logo depois de terminado o curso, o salário do profissional dá um salto de $40 \%$ a $70 \%$. Segundo pesquisa da Revista 'Business Week', os estudantes das melhores escolas de MBA, já antes de formados, recebem, em média, três boas propostas de trabalho, que vêm até de companhias de outros paises. Para se ter uma idéia sobre o aumento da procura por esse tipo de pós-graduaçäo, havia três candidatos por vaga, em 1997, para o curso de MBA da FEA-USP (Faculdade de Economia e Adntinistração da Universidade de Säo Paulo). Hoje são seis" (Folha de S. Paulo, 31 de janeiro de 1999).

Contudo, segundo artigo publicado na Folha de São Paulo, "boa parte dos cursos adota o nome MBA somente por já ser uma marca conhecida, mas não săo, necessariamente, cursos de Administração nem têm a mesma carga horária e o mesmo objetivo." Jornal Folha de S. Paulo, 31 de janeiro de 1999). Segundo matéria publicada na Revista Veja, aproximadamente $200 \mathrm{MBAs}$ foram criados no Brasil na década de 1990, sem ter, a maioria, credibilidade quer junto aos orgãos governamentais (Ministério da Educaçāo), quer junto ao mercado. Segundo o articulista, "o governo não controla a qualidade dos MBAs por considerá-los simples especializações, sem o peso de mestrado sugerido pelo nome" (Oliveira, 2000).

O mestrado profissional, por sua vez, constitui-se efetivamente em um mestrado, um curso de pós-graduação strito sensu, não somente um curso de especializaçäo, à semelhança da pós-graduação lato sensu. Chagas Filho, já em 1972, fazia menção a um programa de mestrado com contornos profissionais. Admitia a possibilidade de cursos de pós-graduação com caráter acadêmico e outros que poderiam ser chamados de "profissionais", por se destinarem à melhor formação de quadros, exclufdos os universitários, "para os quais qualquer formação deve ser do tipo acadêmico" (Chagas Filho, 1972: 242).

Já em 1985, no Relatório Final da Comissão Nacional para Reformulação do Ensino Superior, havia uma menção a um curso de pósgraduação (diferenciado do lato sensu), com contornos de um mestrado não-acadêmico. A Comissão defendia o

"incentivo, fortalecimento e valorização dos programas de pós-graduação de cunho profissional e de formaçäo para o magistério, buscando-se desenvolver modelos igualmente prestigiados, mas alternatioos aos mestrados $e$ doutorados de pesquisa hoje predominantes" (Brasil, 1985:85). 
Segundo a Portaria $\mathrm{n}^{\circ} 080$ de dezembro de 1998, expedida pela Capes, os mestrados "profissionalizantes" devem ter uma estrutura curricular clara e consistente, um quadro docente qualificado (com a predominancia de doutores), uma carga horária adequada (admitindo-se a dedicação parcial ao curso) e devem exigir a apresentação de um trabalho final de curso compatível com a natureza da área de estudo (não necessariamente a dissertação) (Capes, 1998).

Com o intuito de fornecer diretrizes para a instalação dos mestrados profissionais, foi constituída pela Capes, em 1995, uma comissâo presidida pelo professor Darcy Dillenburg e composta pelos professores de Direito, Silvino J. L. Neto (UFRGS) e Edson de O. Nunes (Cândido Mendes), de Administraçāo, Tania Fischer (UFBA) e Jacques Marcovitch (USP), de Engenharia Mecânica, Luis Bevilacqua (UFRJ) e de Computação Augusto F. Almeida (UFMG). É digna de nota a ausência de professores da área de Educação dentre os membros da Comissão, o que revela, em primeiro lugar, o principal mercado para tais cursos e, em segundo lugar, a possivel resistência dos educadores a essa modalidade de mestrado. A Comissão produziu um documento, "Mestrado no Brasil - A situação e uma nova perspectiva", que foi acolhido pela Capes dando origem ao "Programa de Flexibilização do Modelo de Pós-Graduação Senso Estrito em Nivel de Mestrado".

O Regimento Geral de Pós-graduação da Unesp de 1999 contempla as duas modalidades de mestrado. Em seu artigo $2^{\circ}$ o Regimento dispõe que "a pós-graduaçāo na UNESP será organizada em Programas "stricto sensu" - Mestrado Acadêmico, Mestrado Profissionalizante e Doutorado, e "lato sensu" - Aperfeiçoamento e Especialização" (Unesp, 1999: 1). Segundo o Regimento, mesmo na "opção" pelo "trabalho equivalente" como alternativa à dissertação, há a necessidade de apresentação pública. Segundo o Artigo 39, "a dissertação ou trabalho equivalente será apresentada pelo candidato perante uma comissão examinadora, que o argüirá em sessăo pública" (Unesp, 1999: 10).

Para muitos, o mestrado profissional seria uma alternativa viável. Nesse tipo de mestrado o aluno não se dedicaria tanto à pesquisa (dedicação esta própria do mestrado acadêmico, que exige a dissertaçâo de final de curso), tendo outras alternativas de trabalho final, tais como, um relatório de projeto de consultoria, a aplicação de uma técnica a uma realidade concreta, um estado da arte (revisão de bibliografia) ou um certo número de artigos publicados em periódicos de peso em sua área (Sueth: 74). Durham, Schwartzman e Bresser Pereira estão entre aqueles que defendem o mestrado profissional como alternativa ao mestrado acadêmico, mais tradicional, voltado à qualificação científica, com ênfase na 
pesquisa (Folha de S. Paulo, 14 de julho e 9 de outubro de 1991). Nos dizeres de Fátima Bayma de Oliveira, "o que se pleiteia não seria uma amputação de parte do mestrado, mas uma possível alternativa para evitar a evasăo de alunos que carecem de vocação teórica" (Oliveira, 1995: 171). Oliveira não defende abertamente o mestrado profissional, mas questiona o mestrado acadêmico, afirmando que "nas grandes universidades americanas já não há mais cursos regulares de mestrado. Os alunos ingressam diretamente no doutorado e, ao longo desse processo, caso não tenham fôlego e não consigam escrever a tese, obtêm o título de mestre" (Oliveira, 1995: 116).

Um problema importante do mestrado profissional refere-se a concepção de pesquisa que o mesmo traz embutida. A urgência de qualificaçăo associada ao exiguo tempo levam a um problemático pragmatismo científico: só se justifica pesquisar aquilo que terá uma aplicação prática a curto prazo; percebe-se nesse meio a predominância de uma concepção excessivamente utilitarista de pesquisa.

\begin{abstract}
"Seria mistificação chamar-se de 'pós-graduação' um curso que apenas oferecesse informaçōes e ensinasse técnicas, por mais avançadas que fossem. (...) A pesquisa cientificamente conduzida é o instrumento de escola para desenvolver a capacidade de pensar e de criar, estimulando o raciocínio $e$ levando-o a projetar-se no campo das realizaçōes práticas. Dá, constituir-se a pesquisa, a investigação científica, na pedra angular dos cursos de pósgraduaçäo" (Campos, 1972: 236).
\end{abstract}

É de se salientar que a pesquisa no país está diretamente ligada à pós-graduação. Segundo Severino, "é na prática da pesquisa que a pósgraduação encontra sua legitimidade" (Severino: 193). O vínculo pesquisaposs-graduação já vem desde a regulamentação dos primeiros cursos no Brasil, ainda na década de 60 . Tal vínculo, contudo, não tem uma relação causa-efeito adequada, isto é, nem sempre foi a prática regular de pesquisa que deflagrou o inf́cio dos cursos de pós-graduação. Pelo contrário, "em vez de ser uma decorrência normal do exercício da pesquisa no interior da universidade, é ela que emerge em nosso contexto cultural com processo indutor do pouco de pesquisa que se faz". (Severino: 192).

O ambiente adequado à pesquisa é o de liberdade de produção, sem pressões externas que requeiram uma produtividade a curtíssimo prazo. A pesquisa precisa ser encarada como uma atividade de valor para a instituição, para o individuo e para a comunidade, "independentemente dos proventos materiais imediatos que possa acarretar" (Campos, 1972: 236).

Em oposiçāo ao mestrado profissional estăo, pois, aqueles que vêem na pós-graduação um espaço feito sob medida para a pesquisa. Já no 
Primeiro Simpósio de Política Nacional de Pós-Graduação, em 1972, a presença da pesquisa em todos os programas de pós-graduação foi defendida pelos participantes, que entenderam que "a realização de trabalhos de investigação científica seria uma condição sine qua non para todo aquele que busca os graus de Mestre ou de Doutor" (Campos, 1972: 335).

Contra a idéia do mestrado desvinculado da pesquisa pode-se citar, também, a crítica feita por Darcy Ribeiro, em 1980, à concepção profissionalista da universidade, que "assumiu a responsabilidade de dar para cada curso um diploma ao qual corresponda um emprego. Isto não existe, Universidade é agência do saber, não de emprego. Sua função é elevar a pessoa a um nivel mais alto de versatilidade intelectual" (Ribeiro, 1980: 78). Nessa mesma linha argumentou Hamburger, ao questionar a hipervalorização das provas escritas e exames em detrimento da elaboração da tese/dissertação.

"Ainda é no trabalho de pesquisa que o estudante tem maior possibilidade de amadurecimento e criaçäo. Se se quer treinar um pesquisador, evidentemtente - elemento para julgar se ele é capaz ou näo de realizar pesquisa boa é a própria pesquisa que realiza, e que está consubstanciada na tese" (Hamburger, 1980: 89).

As avaliaçöes institucionais tendem a favorecer os cursos mais "enxutos" que tenham maior produtividade (em termos de números de papers, artigos), mesmo que sem a devida profundidade e qualidade. Tal postura

"tende a favorecer utilidades de curto prazo, sejam elas cursos curtos em detrimento de cursos longos, formaçães unidireccionadas em detrimento de formaçōes complexas, investigaçāo competitioa em detrimento de investigação pré-competitiva, reciclagem profissional em detrimento de elevação do nfoel cultural, etc., etc." (Santos, 1995: 218).

Freitag analisou criticamente a logica capitalista que orienta programas e cursos, crítica esta que pode ser estendida aos mestrados profissionais.

“... a economia da educaçāo precisa enfatizar que a educação só é investimento quando prepara os individuos para o trabalho. Não é mais um processo de transmissão de cultura geral de humanidades, de saber universal. A educação é instrumentalização para o trabalho. Ela é investimento quando prepara o indiofduo profissionalmente a fim de que seja mais produtioo na empresa que o contrata. Portanto não é mais um processo que liberta o individuo do trabalho (especialmente manual) e, conferindo-lhe o titulo de doutor, o eleva à classe dominante, mas um processo que o habilita para o trabalho, para ai entâo ascender na hierarquia ocupacional, mediante melhores salários" (Freitag: 108). 
Na área da Educação é muito forte a resistencia ao mestrado nãoacadêmico. $\mathrm{O}$ mestrado profissional em Educação poderia representar o resgate do tecnicismo na pós-graduação. Grande parte dos educadores entendem que tal sistema desvaloriza o diploma de mestre e se sobrepōe à pós-graduação lato sensu (Oliveira, 1995 : 161). Contra o imediatismo do mestrado profissional em Educação, cabe a reflexão feita por Mendes:

\begin{abstract}
"É sabido que as idéias só influenciam os fatos quando distanciadas deles por um longo periodo de germinação. Se quisermos mantê-las rentes com os fatos, elas perdem a força fertilizadora.(...) Neste sentido, nada mais urgente para a educaçüo brasileira que o exercicio de um pensamento não-urgente, apesar de inteiramente entrosado com os fatos" (Mendes: 254).
\end{abstract}

Uma questão importante acerca dos mestrados profissionais referese ao espaço que os mesmos irão ocupar. Em 1998 foram abertos cerca de $20 \%$ dos 70 cursos de pós-graduação lato sensu da USP, enquanto o crescimento de cursos de pós-graduação stricto sensu foi de apenas $8 \%$; já na Unesp foram abertos neste mesmo ano 36 novos cursos de pós-graduação lato sensu e apenas 12 cursos stricto sensu (Avancini, 1999(a)). Tal crescimento das especializaçŏes, em detrimento dos mestrados "acadêmicos", pode tanto revelar um aumento na demanda por cursos de pós-graduação com feitios mais profissionalizantes como indicar uma atitude cautelosa das universidades quanto à implantação dos mestrados profissionais.

O perigo da superficialidade dos mestrados profissionais pode ser atestado nos dizeres de um artigo publicado na Folha de São Paulo em janeiro de 1999. Segundo o artigo, vários professores da área de administração entendem que, o problema do programa convencional, isto é, o mestrado acadêmico, é ter se tornado uma exigencia na carreira dos profissionais mas estar dirigido àqueles que querem estudar uma assunto profundamente. "E isso não casa com as necessidades do mercado de trabalho, que busca resultados rápidos e imediatos', explica Ronaldo Zwicker, 49, coordenador do programa de pós-graduaçāo em administração da USP (Universidade de São Paulo)" (Jornal Folha de S. Paulo, 31 de janeiro de 1999).

Os mestrados profissionais, devido à sua estrutura e propósito, são evidentemente mais superficiais que os mestrados acadêmicos. Estes, na classificação de Boaventura Santos, seriam destinados à formação de produtores, aqueles à formação de consumidores, pois "num caso são necessários conhecimentos específicos, no outro são necessários conhecimentos gerais, a tendência para privilegiar a formação de consumidores acabará por se repercutir no núcleo curricular" (Santos, 1995: 197). 


\section{Referências Bibliográficas}

ALTMAN, F. Fantasmas da Academia. Revista Veja. $1^{\circ}$ semestre de 1995. p.62,63.

ALVARENGA, J. B. de. Pós-graduação no Brasil: institucionalização e situação atual. (Tese de concurso) Universidade Federal Fluminense, Niter6i, 1980.

AVANCINI, M. Formação atende ao mercado - Brasil so tem 7 mestrados profissionais. Jornal Folha de S. Paulo. 16 de agosto de 1998.

AVANCINI, M. Conselho Federal libera pós profissionalizante em empresa. Jornal Folha de S. Paulo. 11 de janeiro de 1999.

AVANCINI, M. Cresce procura por especialização. Jornal Folha de S. Paulo. 11 de janeiro de 1999.

BEIGUELMAN, B. Uma análise crítica da pós-graduação no Brasil. Ciência Hoje. 12, (68) p. 18-21, 1990.

BRANDÃO, Z. Evasão e repetência no Brasil: a escola em questão. R.J.: Achiame, 1983.

Brasil. Ordenação em texto único das leis de diretrizes $e$ bases da educação nacional e legislaçâo conexa. Brasilia; CFE, INEP e comissão de Bducação e Cultura da Camara dos Deputados, 1983.159 p.

Brasil, Ministério da Educação. Uma nova polftica para a educação superior. Relatório Final. Brasilia, 1985.

Brasil, Capes (Coordenação de Aperfeiçoamento de Pessoal de Nfvel Superior). Documento de Área- Educação. Perfodo de Referência - Biênio 96/97. 1998. 45 págs.

Brasil. Capes (Coordenação de Aperfeiçoamento de Pessoal de Nível Superior) Reformulação do Sistema de Avaliação da Pós-graduaçäo: O modelo a ser implantado na avaliação de 1998 (documento em discussão). Brasilia, 1996.

Brasil, Ministério da Educação. Lei de Diretrizes e Bases da Educaçäo Nacional. Brasflia, 1996.

Brasil. Capes. (Coordenação de Aperfeiçoamento de Pessoal de Nível Superior) Ficha de aoaliação 96/97. Programa de Pós-graduação da Unesp/Marilia, 1998.

Brasil. Capes. (Coordenação de Aperfeiçoamento de Pessoal de Nfvel Superior) Portaria $n^{\circ} 080.16$ de dezembro de 1998.

BRAVO, L. A pós-graduação no Brasil. Revista Brasileira de Estudos Pedagógicos. 58 (128), p. 388-397, 1972. 
CAMPOS, M. A. P. Política de pós-graduação no Brasil. Revista Brasileira de Estudos Pedagógicos. 58 (128), p. 232-240, 1972.

CAMPOS, M. A. P. Informe do $1^{\circ}$ Simpósio de Política Nacional de pósgraduação. Revista Brasileira de Estudos Pedagógicos. 58 (128), p. 335-339, 1972.

CAPRILES, R. Makarenko: o nascimento da pedagogia socialista. São Paulo: Scipione: 1989.

CHAGAS FILHO, C. Atualidades e perspectivas da pós-graduação. Revista Brasileira de Estudos Pedagógicos. 58 (128), p. 241-248, 1972.

CLOSS, I. G. Mestrado em Educação no Brasil: retenção e produtividadeCadernos de Pesquisa. 27: 41 - 57, 1978.

CLOSS, I. G. O enfoque sistêmico da pós-graduação no Brasil - Educaçüo e Realidade. 4 (1), p. 121 - 134, Porto Alegre, 1979.

COELHO, I. Sinecura Acadêmica. São Paulo, 1985.

CUNHA, L. A. A pós-graduação no Brasil: função técnica e função social. Revista de Administração de Empresas. 14 (5), p. 66-70, 1974.

CUNHA, L. A. Pós-graduação em educação: no ponto de inflexăo?Cadernos de Pesquisa. 77, p. 63-80. 1991.

DELUIZ, N. Avaliação do curso de mestrado em educação da Universidade Federal do Rio de Janeiro. (Dissertação de mestrado) UFRJ, 1978.

ECO, U. Como se faz uma tese. São Paulo: Perspectiva, 1983.

FARIA, R. B. Pesquisador velho é pesquisador morto? Jornal da Ciência. $\mathrm{n}^{\circ}$ 356. Rio de Janeiro, 15 de novembro de 1996.

FAZENDA, I. (org.) A pesquisa em educação $e$ as transformaçōes do conhecimento. 2 ed. SP: Papirus, 1997.

FREITAG, B. Escola , Estado e Sociedade, 4 ed. São Paulo: Moraes, 1980.142 p.

GATTI, B. A. Alternativas metodológicas para a pesquisa educacional: conhecimento e realidade - Cadernos de Pesquisa. 49, p. 3-14, fev. SP: Fundaçäo Carlos Chagas, 1982.

GATTI, B. A. Pós-graduação e pesquisa em educação no Brasil: 1978-1981Cadernos de Pesquisa. 44, p. 3-17. São Paulo, 1983.

GATTI, B. A. Formar professores ou pesquisadores no Mestrado em Educação- Boletim Anped. 1, p. 31-40, jan./mar., 1987.

GÓES, P. Aspectos administrativos da educação pós-graduada no Brasil. Revista Brasileira de Estudos Pedagógicos. 58 (128), p. 224-231, 1972. 
GOIS, A. Salto de Qualidade. Revista Veja. 49, 8 de dezembro de 1999. p. 32,33 .

GOLDSCHMIDT, D. Estudos de Pós-Graduação na Alemanha. São Paulo: NUPES, 1996.

GRACIAREMA, J. Pós-Graduação em Ciências Sociais na América Latina. Revista Brasileira de Estudos Pedagógicos. 58 (128), p. 265-280, 1972.

HAMBURGER, E. Para que pós-graduação? Encontros com a Civilizaçâo Brasileira. RJ: Civilização Brasileira, 1980.

ISSAC, P. D. et all . Factors related to doctoral dissertation topic selection. Research in Higher Education. 4 (30), USA, 1989.

Jornal Folha de S. Paulo. Seminário aroalia a crise da pós-graduaçäo. 14 de julho de 1991.

Jornal Folha de S. Paulo. O mestrado subdesenvolvido. 9 de outubro de 1991.

Jornal Folha de S. Paulo. Mestrado profissional ganha espaço- Programas se voltam para o mercado. 31 de janeiro de 1999.

Jornal Folha de S. Paulo. Mestrado pode desaparecer. 31 de janeiro de 1999.

Jornal Folha de S. Paulo. PSEUDONIMO- Cursos que adotam a sigla nem sempre seguem o conceito original, criado nos EUA para administração. 'Escolas inventam MBA à brasileira'. 31 de janeiro de 1999.

Jornal Folha de S. Paulo. EM ALTA. Remuneração acima da média faz aumentar procura por aḋministraçūo de negócios- $M B A$ eleva salários em até $70 \% .31$ de janeiro de 1999.

Jornal $\mathrm{O}$ Estado de S. Paulo. Chega a $50 \%$ a evasĩo de alunos nos cursos de pósgraduaçāo. São Paulo. A16. 16/05/95.

KAFURI, R. (coord.) Pesquisa sobre eoasäo, repetência e fatores condicionantes. Goiania: UFG, 1985.

KAMERGORODSKI, B. C. Pós-graduação nos Estados Unidos- relato de uma experiência. Revista Brasileira de Estudos Pedagógicos. n. 58 (128), p. $346-$ $351,1972$.

LEMOS, D. G. et alii. A evasäo escolar no curso de Mestrado em Educaçäo. Faculdade de Educação. Universidade Federal Fluminense. (mimeo.), 1991.

LUDKE, M. A. \& ANDRÉ, M. E. Pesquisa em educação: abordagens qualitativas. São Paulo: EPU, 1986.

MENDES, D T. Pesquisa e Ensino no Mestrado de Educação. Reoista Brasileira de Estudos Pedagógicos. 58 (128), p. 249-264, 1972. 
OLIVEIRA, F. B. Pós-graduação- Educação e mercado de trabalho. São Paulo: Papirus, 1995. 202 p.

OLIVEIRA, M. Arapuca de MBAs. Revista Veja, 37, 13 de setembro de 2000.

OLIVEIRA, T. F. R. Dissertaçäo e teses na pós-graduação: diferenças. UFMG, 1997. (mimeo.)

PAIVA, A. (org.) Reflexões sobre a Pós-graduação em Educaçäo no Brasil: A experiencia da FaE/UFMG. Belo Horizonte: Autentica, 1997.

PATTO, M. H. S. A produção do fracasso escolar. SP: T. A. Queiroz, 1993.

PRADO, F. D. Acesso e evasäo de estudantes na graduação: a situação do curso de física da USP. (Tese de Doutorado), USP, 1990.

SANTOS, B. S. Pela mão de Alice - o social e o político na pós-modernidade. São Paulo: Cortez, 1995.

SANTOS, C. M. O acesso ao ensino superior no Brasil - a questão da elitização. Revista Ensaio. 19 (6). Rio de Janeiro: Cesgranrio, abril-julho, 1998.

SANTOS, C. M. A proletarização do trabalho docente: entre o mito, a realidade e a possibilidade. Trabalho \& Educação- Revista do NETE. $n^{\circ} 4$, Belo Horizonte: NETE/UFMG, agosto/dezembro, 1998.

SANTOS, C. M. Tradiçōes e contradicões da pós-graduação no Brasil: uma análise da eoasäo de estudantes no mestrado em Educaçẫo da Unesp/Marilia., Unesp Marilia, 2000.

SARMENTO, D. C. Cursos de pós-graduação em educação: Influência sobre a percepção de seus egressos quanto a problemas educacionais brasileiros. Tese de doutorado, Rio de Janeiro, Faculdade de Educação/ UFRJ, 1986.

SCHWARTZMAN, S. Formação da comunidade cientifica no Brasil. SP: Nacional/FINEP, 1979.

SCHWARTZMAN, S. (rel.) Sub-comissão de Pós-graduação e pesquisa. Universidade, Pesquisa e Pós-graduação. Ciência Hoje. 4 (20), p. 82, 1985.

SEVERINO, A. J. A pós-graduação, o conhecimento e a formação do educador. Formaçäo do educador e avaliação educacional. v.2. São Paulo: Editora Unesp, 1999.

SOARES, M. B. Linguagem e escola. 2a ed. SP: Ática, 1986.

Sociedade Brasileira para o Progresso da Ciência. CNPq e Capes vão cortar bolsas. Jornal da Ciência. 360, Rio de Janeiro, 21 de fevereiro de 1997. 
SUETH, R. Alternatioas à dissertnçäo: eventual soluçāo para reduzir a evasäo de alunos nos mestrados em Educaçẫo. UFRJ, Faculdade de Educação, 1995. (dissertação de mestrado).

UNESP/Universidade Estadual Paulista. Programa de Pós-Graduação em Educação. Cursos de Mestrado e Doutorado Acadêmicos. Marilia, 1999.

UNESP/Universidade Estadual Paulista. Regimento Geral de Pós-graduaçäo da Unesp. São Paulo, 1999.

ZANCAN, G. Análise da avaliação da Capes. Jornal da Ciência. 360, Rio de Janeiro: SBPC, 16 de maio de 1997. 


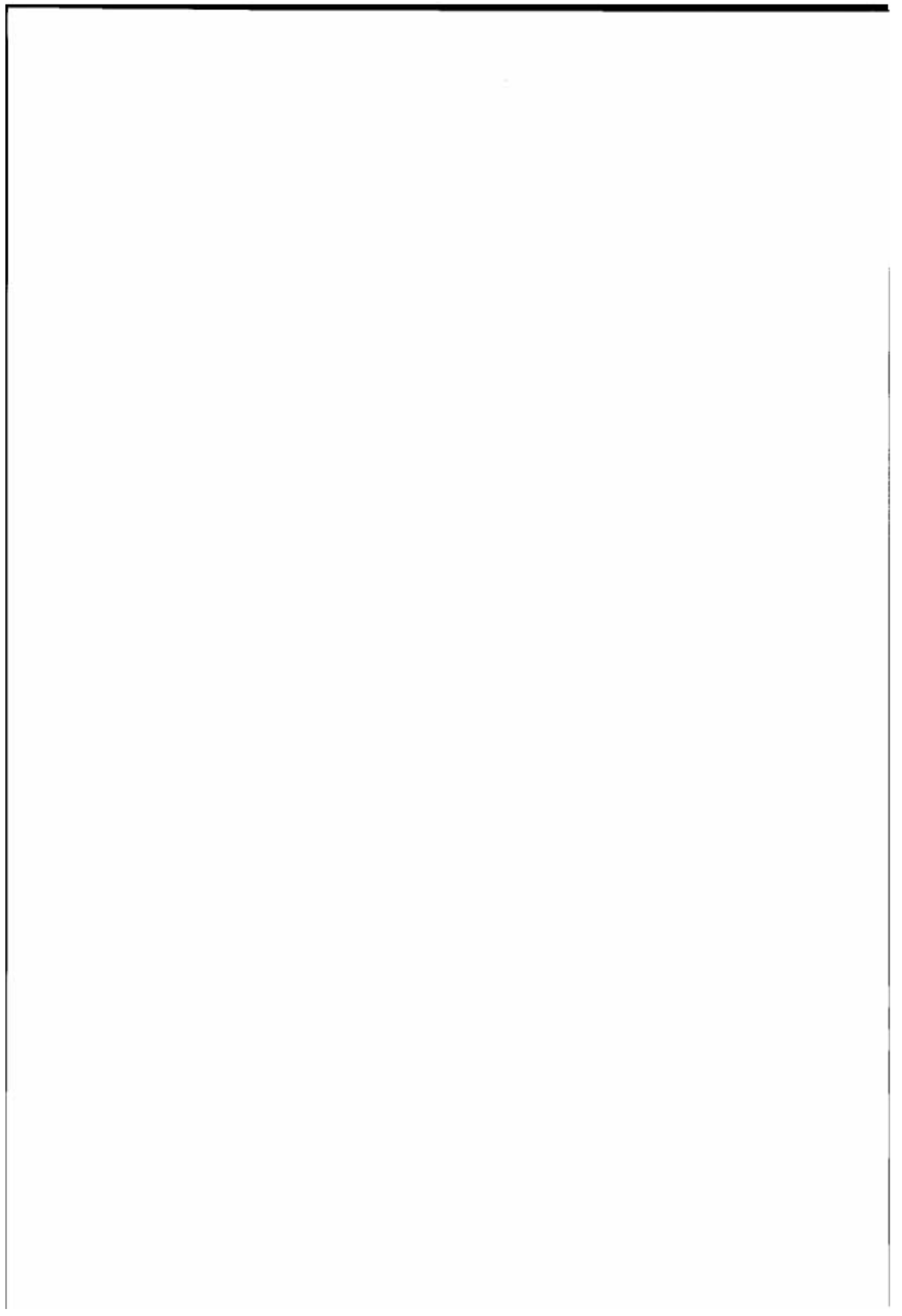

